\title{
The Appropriateness Of Parental Involvement In The Job Search Process
}

Gary S. Insch, West Virginia University, USA

Joyce Heames, West Virginia University, USA

Nancy McIntyre, West Virginia University, USA

\begin{abstract}
This paper explores millennial job seekers and their parental involvement in the job search process. Preliminary work on a scale to measure the "appropriateness" of certain job search behaviors is reported. Ten parental job search behaviors are identified. The appropriateness constructs of "mentoring" and "meddling" are developed and empirically tested. Results indicate that both meddling and mentoring are valid and initially useful constructs in examining the suitability of parental involvement in the job search process. The possible impact of parental involvement in the job search process is then discussed along with possible managerial responses.
\end{abstract}

Keywords: Helicopter parents; job search process

\section{INTRODUCTION}

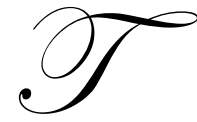

hree things are apparent in the job search literature. First, attracting talented people is a time consuming, difficult and complex process. Second, applicants from the millennial generation who are entering the job market today are different from applicants of the past on many dimensions. Moreover, these young applicants are no longer the only, nor possibly even the main decision maker, in their own job search process.

As the millennial generation has entered the job market, many studies have provided profiles. Raines (2003) stated that these young people are sociable, optimistic, talented, well-educated, collaborative, open-minded, influential, and achievement-oriented. As companies seek to entice these talented young workers, they have begun to realize that they may need to attract more than just the young person. They may also need to convince the parents of these young stars that their company has the environment, opportunities, and benefits that their child needs to develop his or her career. Indeed, Keith Dugdale, director of global recruitment at KMPG, recently stated "More direct parental involvement is a global phenomenon, and if we want top talent, then we as employers have to make allowances for it" (Matthews, 2008, p. 2).

Reaching high school and then college age, it became clear that the parents of the millennials were often much more involved in their children's lives than any generation before them. These parents spent countless hours arranging schedules and taking their children to sports practice, music lessons, tutoring sessions, and enrichment classes. These Baby-Boomer and Generation-X parents hired consultants to help their children through the college application process. Moreover, they earned a reputation for calling their children each morning to wake them up for school or work and complaining to professors or bosses about their children's grades or performance reviews. These parents became known as "helicopter parents" (Cline \& Fay, 1990). The term became widely used in the 1990's to define parents who seemed to be embedded in their children's lives and paid an extraordinary amount of attention to the activities of their children. And there are some who believe that students whose parents intervened during the college years were "more active in and satisfied with college" (Lipka, 2007)

Now, as these young people enter the job market, it has been reported by many companies that these types of "hovering" behaviors are continuing in the job search process and even into the workplace. Articles in the popular press report parents attending career fairs, contacting potential employers, scheduling job interviews, and going with their children to job interviews. 
While many employers complain about these types of behaviors, other companies argue that in their search for the best and the brightest job candidates, it makes sense to reach out to the parents. According to Forbes magazine (Are Parents Killing Their Kids' Careers? November 9, 2006), companies such as Merrill Lynch, Office Depot, and Enterprise Rent-A-Car include parents in their recruiting efforts. USA Today (Helicopter Parents Hover When Kids Job Hunt, April 23, 2007), reports that recruiters at Hewlett-Packard often have parents attending job fairs and even calling to discuss their son's or daughter's salary, relocation package, and scholarship programs.

On the other hand, some employers are concerned that these "helicopter kids" may lack important managerial skills such as decision making skills and the ability to deal with pressure or crisis. With the hypercompetitive customer-oriented markets in which most companies find themselves today, they need to hire employees who can think on their feet and make sound decisions quickly, effectively, and often independent of direct supervisors. The fear is that the constant doting and intervention by parents throughout their childhood may leave the millennial without the ability to cope in such an environment. Whether you support this type of parental involvement in the job search process, or not, it is becoming more and more prevalent and both practitioners and academic researchers need to understand more about millennial job seekers and the impact of parental involvement in the job search process and early career decisions of these young job applicants.

To our knowledge, there is no empirical research on the impact of parental involvement in the job search process and early career of today's job candidates. In an effort to begin to understand this phenomenon and the cost/benefits to applicants and organizations, we have begun a longitudinal research project. The general research questions driving the first phase of this study are: Who are the "helicopter kids" of the millennial generation, and what level of parental involvement do these young people feel is appropriate in the job search process?

In this paper, we begin by discussing the characteristics of today's millennial generation job seeker and discuss the phenomenon of parental involvement in the job search process. Next, we explore the appropriateness (good versus bad) of parental behavior in relations to the job search process. We report the empirical findings of our initial study, designed to explore the characteristics of helicopter kids and their attitude toward parental involvement in the job search process. We discuss possible managerial strategies for dealing with helicopter kids and their parents, and finally, we suggest future research directions that seem appropriate to better understand this phenomenon and the impact it may have on today's job search process.

\section{GENERATIONS IN THE WORKPLACE}

For the first time in history we have four generations working side by side in the workplace. Defined by demographics and key life-events that shape them, these generations have distinctive characteristics in the workplace. Although there is some disagreement about the exact years of birth, the four generations are 1) Traditionalist - 1922-1945, 2) Baby Boomers - 1946-1964, 3) Generation X'ers, 1965-1980, and 4) Millennials 1981-2000 (Raines, 2003).

According to Raines (2003), Traditionalists, defined as employees over 60 in 2006, are credited with defining the typical workplace as we know it. The average workday is from 8:00 a.m. to 5:00 p.m. with frequent evening and weekend work. In the workplace, Traditionalists are frugal, hard-working conformists who respect authority and put duty before pleasure. They have spent their career with one or two employers.

The children of Traditionalists are termed Baby Boomers. According to the U.S. Census Bureau, there are 78.2 million Baby Boomers (born between 1946 and 1964) in the United States. Having been raised by Traditionalists, they have a strong work ethic, are often dual-career employees, they value personal growth, hard work, individuality, and equality between the sexes. Professionally, they have lived through downsizing, reengineering, and multiple employers. Many have changed careers numerous times and are leading a trend toward delayed retirement.

The Generation X'ers, born between 1965 and 1980, are independent, resilient, and adaptable. They represent a relatively small segment of the working population and are sometimes termed the "baby bust" generation as families became smaller and divorce became more common. They were often the product of single family homes 
and many were "latchkey" kids. Many entered the workplace in the early 1980's when the economy was in a downturn and they take employment seriously. In the workplace, they are pragmatic, loyal, and team players, but unlike their parents, they tend to put family first and work second.

The fourth generation of employees entering the workplace is the Millennials. According to Raines (2003), Millennials arrive in the workplace with higher expectations than any generation before them. They are the most connected, both socially and technologically, generation in history and will network right out of their current workplace if their needs are not met. They have been exposed to diverse lifestyles and cultures in school at an early age, and tend to respect different races, ethnic groups, and sexual orientations. They are comfortable with computer technology, immediacy, and multitasking. Moreover, they want creative challenges and projects with deadlines, along with job flexibility, telecommuting options and the ability to work part-time or to leave the workforce temporarily when having children.

\section{THE MILLENNIAL GENERATION JOB SEEKER}

The Millennial Generation, also termed the Internet Generation, Echo Boomers, the Boomlet, Nexters, Generation Y, the Nintendo Generation, and the Digital Generation are the children of Baby Boomers and Generation X'ers. According to Howe and Strauss (2000), they are the "Babies on Board" of the early Reagan years, the "Have You Hugged Your Child Today" sixth graders of the early Clinton years, and the teens of Columbine.

According to Raines (2003), these young people are sociable, optimistic, talented, well-educated, collaborative, open-minded, influential, and achievement-oriented. In a survey of 7,705 college students done by Junco and Mastraodicasa (2007), 97\% own a computer, 94\% own a cell phone, 76\% actively use instant messaging and social networking sites, $75 \%$ have a Facebook profile that they check daily, and $60 \%$ own some type of portable music and other media using peer-to-peer file sharing. Many of these young people have been praised, pampered, and protected with every step of their lives structured by their parents. They are instantly attached to their friends and family via cell phones, instant messaging, e-mail, and other technology.

\section{HELICOPTER PARENTS}

Many of the Millennials are the product of parents who have been very involved in their lives. While it is unarguable that being involved in a child's life is important, some parents may have become over-involved. These parents are now known as helicopter parents, with the worst being labeled Blackhawks (Somers \& Settle, 2008). They have programmed their children's lives through grade school, high school, and college and many are now attempting to handle their child's job search process. It is commonly reported that parents are writing their children's resumes, coaching their kids for interviews, attending job fairs, contacting potential employers on their child's behalf and even going to job interviews with their children.

The research on helicopter parenting in the job search is scarce, but extensive research has been done with regard to helicopter parenting during the academic process. In a recent paper which explores helicopter parenting from the perspective of academic services at universities, Somers and Settle (2008) present an excellent discussion of the cultural factors that have led to helicopter parenting behavior and offer a typology of five types of helicopter parents. These include 1) the consumer advocate, 2) the equity or fairness advocate, 3 ) the vicarious college student, 4) the toxic parent, and 5) the safety patrol parent.

- The "consumer advocate" views college as a consumer transaction where their role is to act as a copurchaser with their child. These parents contact administrators to negotiate everything from the right residence hall room to the right class schedule. They view their child's education as a service-oriented transaction based on the exchange of goods or services for a price.

- The "equity or fairness advocate" seeks the best of everything for their child; the best residence hall, the best major, the best professors. Although they may couch their arguments in fairness, according to the authors, these parents are actually demanding better, rather than equal treatment and services for their child.

- The "vicarious college student" may have missed out on many college experiences and appear to reliving those years through their child. They attend every activity, parent weekend, and sporting event. 
- $\quad$ The "toxic parent" has been discussed in the literature (Neuharth, 1998) as parents with control issues. They are often negative in their interaction with their child and prone to "one-upping" their child in every situation.

- Finally, the "safety patrol parent" is concerned with the safety of their child. They often request information on policies and procedures for handling emergencies (i.e. fire or terrorist attacks).

Somers and Settle (2008) go on to discuss factors that may be contributing to the increase in helicopter parenting. These factors include tremendous demographic shifts in America leading to more college-eligible children and the growing perception of education as a commodity. The market place is also facing significant change with the globalization and outsourcing of jobs that leads to increased competition for the remaining jobs in America. Security and terrorism are at the forefront of most people's minds, especially parents, with the highly publicized abduction of a number of college students in the United States. There are also psychological shifts in the perception of college students from adults to "emerging adults" (Arnett, 2007) with parents willing to take over more responsibility and who expect less from their children. Finally, there are changes in family dynamics and parenting with the possibility of overindulgence by single and/or divorced parents and advances in technology, which enable more interaction with their child.

\section{PARENTAL INVOLVEMENT IN THE JOB SEARCH PROCESS}

While helicopter parenting in the job search process has been the buzz in the popular press, very little research has been reported in the academic literature. One of the few, but very enlightening studies was recently published as a research brief by the Collegiate Employment Research Institute at Michigan State University (2007) where 725 employers responded to a Michigan State University recruiting survey. In that report, Phil Gardner, the Director of the CERI discussed increased parental involvement in their children's transition from college to work. When asked to indicate how frequently they observed parental involvement in the recruiting process and early career stages of college students (on a five-point scale from "not at all" to "very often"), $32 \%$ of respondents from companies with greater than 3,688 employees indicated that they interacted with parents "sometimes" to "often." In companies from 351-3,687, 26\% reported interaction. For companies with 61-350 employees, 23\% reported interaction, while in smaller companies, with less than 60 employees, only $12 \%$ reported interaction with parents. Additionally, employers who recruited heavily on college campuses, companies with strong co-op and internship programs, and employers recruiting in the Northeast and Northwest all reported high incidents of engaging parents during the recruiting process.

The types of involvement that Gardner reported ranged from simply obtaining information on the company to actually attending the interview. In order to collect this data, Gardner provided a list of nine possible activities, taken from media stories and discussions with employers and presented them to the respondents. The respondents were asked to report how many of these activities they had personally witnessed. These types of involvement are shown in Table 1.

While the majority of the discussions in the popular press and in academic research have focused on helicopter parenting, no research has addressed if these behaviors are viewed as appropriate or inappropriate. Somers and Settle's (2008) typology of helicopter parent carries the tone, if not the direct implication, that parental involvement in the college academic process is not viewed favorably and may even be harmful. This is an interesting contrast to the commonly held belief that parental involvement in the elementary and secondary school level is for the most part highly desirable. 
Table 1: Types of Parental Involvement

(Excerpted from Gardener, 2007, CERI- Michigan State)

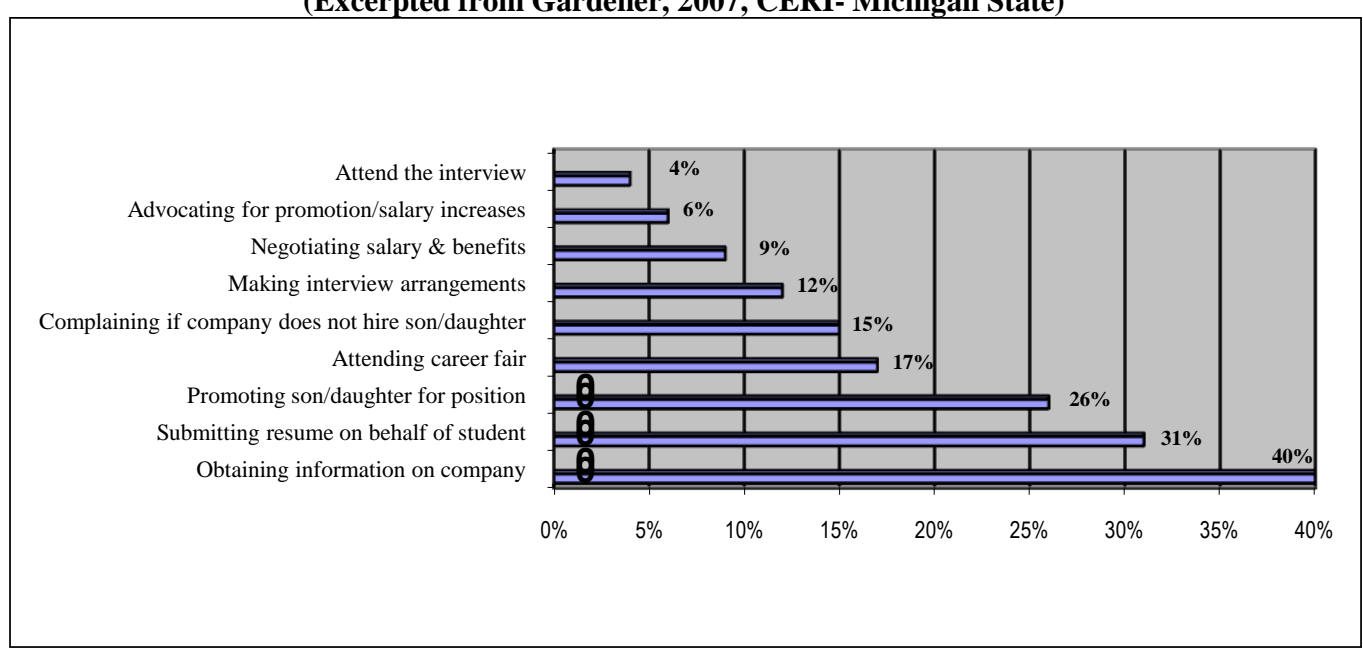

As the discussion regarding the appropriateness of helicopter parental behavior has evolved in the business press, the verdict is decidedly mixed. Some authors, parents and millennial job seekers welcome parental involvement, while others argue against it. Consequently, an interesting paradox emerges. Are there beneficial and appropriate parental job search behaviors?

Moreover, there is no empirical research on the next important issue: how do these "helicopter kids" feel about parental involvement. Do they believe the behaviors shown in Table 1 are appropriate? Do they want their parents involved in their job search processes? In order to explore the phenomenon of appropriate parental job search behaviors and helicopter kids, we have begun a longitudinal study which identifies different types of parental involvement and we examine millennial job seekers perceptions of the appropriateness of these types of involvement in the job search process. In the next section, we will report the initial findings of this study.

\section{METHODOLOGY}

Because this was an exploratory study, a range of data collections methods were used in order to identify types of parental involvement in the job search process. All data were collected from juniors, seniors, and MBA students enrolled at a large Mid-Atlantic, state university.

One hundred twenty eight students enrolled in online business courses were offered extra credit to participate in an online survey which asked them to read two business press articles on "helicopter parents." The participants were then asked to list appropriate and inappropriate helicopter parenting behaviors and give examples of helicopter parenting behavior they had witnessed. Forty-six usable responses were collected. Additionally, 96 undergraduate seniors were invited to participate in a focus group for which they would receive extra credit. Twenty-one students participated and were broken into two separate focus groups. Each group was also presented the same two business articles and then asked a list of questions similar to those on the online survey. The behaviors gathered from the online questions and the focus groups were classified into seven groups:

1. Pre-college behavior

2. Early college behavior

3. Student-initiated contact behavior

4. Student-initiated support behavior

5. Parent-initiated contact behavior

6. Parent-initiated support behavior

7. Job search behaviors 
Based on the limited existing literature and these surveys and focus group results, a preliminary survey was developed. As a pre-test, this survey was administered to 34 Masters of Industrial Relations/Human Resource Management students as an in-class assignment. These students were asked to fill out the survey and were encouraged to write comments on the survey regarding the clarity of the questions and overall presentation and format. Because this study was focused on job search behaviors, only those behaviors were used in the next phase of this study.

\section{THE APPROPRIATENESS OF PARENTAL INVOLVEMENT IN THE JOB SEARCH PROCESS}

Ten parenting behaviors in the job search process were identified. These included:

1. Giving advice about a job.

2. Helping write a resume/cover letter.

3. Giving advice about what to wear to a job interview.

4. $\quad$ Going to job fairs with the student/applicant.

5. $\quad$ Filling out job applications.

6. Traveling to the town where the job interview was to occur, but not attending the interview.

7. Attending a job interview with the student/applicant.

8. Contacting recruiters for the student/applicant.

9. Contacting others in the company to which a student/applicant is applying or wanting to apply.

10. Setting up job interviews.

A questionnaire asking the appropriateness of these behaviors was presented to 340 undergraduate students enrolled at the same university as an extra credit assignment. Of these 340 students, 310 useable surveys were returned, representing a $91 \%$ response rate. The initial factor analysis of the ten behaviors yielded two distinct factors. One question "Going to job fairs with the student/applicant" loaded almost equally on both factors and was dropped from the next iteration of the analysis, which contained the remaining nine behaviors. The first factor, which we call "Mentoring," consisted of the above listed behaviors 1, 2, 3 and 6, and had a Cronbach's alpha of .748. The second factor, which we call "Meddling," consisted of the above listed behaviors 5, 7, 8, 9 and 10, and had a Cronbach's alpha of .773 (See Table 2).

Table 2: Factor Analysis of Parental Involvement Behaviors in the Job Search Process

\begin{tabular}{|c|c|c|}
\hline Factor 1: Mentoring & Factor Loading & Cronbach's Alpha \\
\hline Your parents giving advice about a job & .826 & \\
\hline Your parents helping you write a resume/cover letter & .802 & \\
\hline Your parents giving advice about what to wear to a job interview & .866 & \\
\hline \multirow[t]{2}{*}{$\begin{array}{l}\text { Your parents traveling to the town where the job interview was to occur, but not } \\
\text { attending the interview }\end{array}$} & .506 & \\
\hline & & .748 \\
\hline \multicolumn{3}{|l|}{ Factor 2: Meddling } \\
\hline Your parents filling out job applications for you & .710 & \\
\hline Your parents going with you on the actual job interview & .735 & \\
\hline Your parents contacting the recruiters to encourage him/her to offer you a job & .830 & \\
\hline $\begin{array}{l}\text { Your parents contacting someone associated with the company who might be able to } \\
\text { encourage a recruiter to offer you a job }\end{array}$ & .676 & \\
\hline \multirow[t]{2}{*}{ Your parents setting up job interviews for you } & .696 & \\
\hline & & .773 \\
\hline
\end{tabular}

\section{MILLENNIAL JOB SEEKERS' PERCEPTIONS OF PARENTAL INVOLVEMENT}

Our preliminary findings indicate that some parental involvement is viewed positively by Millennials. When examining specific dimensions of the "mentoring" construct, $87.1 \%$ of the respondents indicated that it was somewhat appropriate or very appropriate for their parents to give them advice about a job, $85.8 \%$ felt it was either 
somewhat appropriate or very appropriate for their parents to suggest what to wear to the job interview, and $68.4 \%$ felt it was somewhat appropriate or very appropriate for their parents to help them write their resume and/or cover letters.

Some middle ground was also found, which further demonstrates the potential ambiguity regarding the "appropriateness" of some behaviors. For example, while $29.7 \%$ of the respondents feel that it was somewhat appropriate or very appropriate for their parents to travel to town where they were having an interview, but not attend the interview, 29.4\% indicated that this behavior was somewhat or very inappropriate. Interestingly, $45.8 \%$ of respondents reported it was somewhat or very inappropriate for a parent to go to job fairs with their children, $32.6 \%$ were indifferent and $21.6 \%$ felt it was somewhat or very appropriate.

Respondent support for the "meddling construct was consistent with the notion that these behaviors may not be appropriate. Almost 59\% of the respondents signified that parental contact with someone in the company with which they are interviewing (See Table 3) was somewhat or very inappropriate. Finally, on the other end of the scale, less than $12 \%$ felt it was somewhat appropriate or very appropriate for their parents to set up job interviews, fill out job applications, contact a recruiter, or attend an interview with them.

Table 3: Students' Responses to Job Search Questions - Helicopter Parenting Survey 1 = Very Inappropriate, $2=$ Somewhat Inappropriate, $3=$ Neither, $4=$ Somewhat Appropriate, 5 = Very Appropriate

\begin{tabular}{|l|c|c|c|c||c||c|}
\hline Question & $\mathbf{1}$ & $\mathbf{2}$ & $\mathbf{3}$ & $\mathbf{4}$ & $\mathbf{5}$ & $\mathbf{4 + 5}$ \\
\hline Parents advice about a job & 3.5 & 1.3 & 8.1 & 38.1 & 49.0 & 87.1 \\
\hline Parents helping write resume/cover letter & 3.5 & 4.5 & 23.5 & 42.6 & 25.8 & 68.4 \\
\hline Parents advice about what to wear to job interview & 2.9 & 0.6 & 10.6 & 43.2 & 42.6 & 85.8 \\
\hline Parents going to job fairs with you & 17.7 & 28.1 & 32.6 & 14.2 & 7.4 & 21.6 \\
\hline Parents filling out job applications & 55.8 & 27.4 & 10.6 & 4.2 & 1.9 & 6.1 \\
\hline Travel to town but not attend interview & 12.9 & 16.5 & 41.0 & 18.7 & 11.0 \\
\hline Parent attending interview & 82.9 & 8.4 & 5.8 & 1.3 & 29.7 \\
\hline Parent contacting recruiter & 78.4 & 11.9 & 6.1 & 1.9 & 1.6 & 2.9 \\
\hline Contacting someone at company & 38.4 & 20.3 & 22.9 & 14.5 & 3.9 & 3.5 \\
\hline Parents setting up job interviews & 38.7 & 25.2 & 23.9 & 9.0 & 3.2 & 18.4 \\
\hline
\end{tabular}

\section{MANAGERIAL IMPLICATIONS}

During the 1980s many undergraduate colleges accepted the philosophy that to attract and retain the best students they must include the parents in the process. Thirty years later that phenomenon is being explored in graduate schools and business. The baby boomers who were encouraged to include their parents in their activities are now being touted as "helicopter parents" because they are more involved in their own children's lives than any generation before them. These parents have made it through their child's undergraduate years and now want to continue to be involved at the graduate school level and the job search process with their children. What does this mean to businesses?

Discussions with recruiters yield a whole spectrum of possible responses that companies might choose with regard to helicopter parenting. There are a few employers who accept the philosophy that they want the best and the brightest and are going to actively recruit millennials and their parents simultaneously. This action is based on the argument that these young people have had strong support from their families as they grew up and are therefore well adjusted, have attended the best schools, and thus are the best job candidates. To that end, they are creating web sites that offer parents information about the company and the recruiting process. These sites often make suggestions on how parents can assist their children as they transition into the workplace. Other employers are going so far as to host a day in which parents and families are invited to visit the child's potential workplace for a few hours, a sort of "Take Your Parents to Work" day.

Some businesses are choosing to draw a line and while they are willing to keep parents informed, they do not include them in the hiring process. They want access to what is perceived to be the best and the brightest, thus 
are willing to put in programs to provide information to parents during their son/daughter's job search process. But that is the line; they do not want parents to participate in the actual interview and will not accept calls from parents.

At the other end of the spectrum, some companies are holding on to traditional recruiting methods and are completely shunning the idea of including parents in the hiring process. They are putting detailed policies into place to prevent the interference of parents. Personnel laws and confidentiality are the main reasons given for not discussing their child or their child's job search process with the parent. They will not move forward with applicants, who wish to involve parents and definitely will not discuss employment arrangements with parents. As one manager stated, "I would never hire a young person who knowingly involved his/her parent in the job search process. I am not hiring their parents and thus our company chooses to do nothing in support of this practice."

Whether the market place is ready to embrace parental involvement in the job search process or not, savvy companies will recognize the new parental mindset and create strategies accordingly. A new position has arisen in 70 percent of colleges, called a parent coordinator (Lum, 2006). The question arises, is this on the horizon for businesses in another three to five years? Regardless of their position on the issue, companies may be forced to have a parent coordinator who at least act as a screener for phone calls from parents wanting more information about the job or wanting to negotiate benefit and salary packages for their son or daughter who is pursuing a job with the company. If they do choose to include parents, the responsibilities of that new coordinator may be to arrange special orientations for the parents of the new class of hires or host conference calls during the hiring process with the parents.

The millennials are closer to their parents than any previous generation. Eleven percent of those between the age of 25 and 34 still live with their parents (Shellenbarger, 2006). Whether parents are more involved from wanting to control their child's life, to protect their investment, or to make sure they get a good job and can move away, the millennial parent is a viable consideration for the modern business. The helicopter parent is here.

Indeed, it is going to cost companies more money to recruit, hire, and onboard the new millennial job seeker, because the parent has to be a part of the equation. There will be cost and time associated with having a specialist in house to help parents know when not to cross the line from mentoring to meddling. Companies are going to be faced with some major decisions that perhaps lead to a revamping of their hiring policies, especially if studies continue to support that parental involvement will ensure the hiring of the best and brightest and that the potential new hire wants their parents to be on boarded as well.

\section{FUTURE RESEARCH}

We have just scratched the surface of the phenomena of helicopter parents and helicopter kids. The second phase of our longitudinal study will start the development of a scale to measure helicopter parenting in an attempt to better understanding the traits and attributes of these hovering parents. Our objective is to develop a general classification/typology of helicopter parents and helicopter kids. We also will endeavor to define a typology of helicopter parenting and how it specifically impacts the job search and into the first few years on the job. The third and final phase of the study will explore more in depth, how employers feel about helicopter behaviors in the job search process? And most importantly determine if helicopter parenting is a valid predictor of job satisfaction and success.

\section{AUTHOR INFORMATION}

Dr. Gary S. Insch is an associate professor of Management and the Director of Graduate Programs in the College of Business \& Economics at West Virginia University. He received his Ph.D. from the Kelley School of Business at Indiana University, Bloomington. Dr. Insch's teaching and research interests are in the areas of: international entrepreneurship; small business planning and performance; expatriate evaluation, training, turnover and repatriation; and liability of foreignness effects on corporate decision-making, foreign direct investment and industrial purchasing. He has been published in Leadership Quarterly, Management International Review, Journal of Business Research, Journal of Business Ethics, Multinational Business Review, Business Horizons, and Journal of International Consumer Marketing. 
Dr. Joyce Thompson Heames, Ph.D., SPHR, is an assistant professor of Management in the College of Business \& Economics at West Virginia University. Her teaching includes human resource fundamentals, staffing and selection, and corporate social responsibility at the graduate and undergraduate levels. Joyce's primary area of research is counterproductive work behavior, specifically workplace bullying. Her work has been published in the Journal of World Business, Journal of Applied Social Psychology, Journal of Leadership \& Organizational Studies, International Journal of Human Resource Management, Management Decision, and Journal of Business Ethics. She serves on the editorial review panel for HRD Quarterly and The International Journal of Conflict Management.

Dr. Nancy McIntyre is the Associate Dean for Academic Affairs in the College of Business and Economics at West Virginia University. She received her Ph.D. in Management/Organizational Behavior from the University of Rhode Island in 1995, and her Masters in Marketing from the University of Illinois in 1990. Dr. McIntyre teaches management and organizational behavior courses. Her publications have appeared in textbooks and numerous professional journals including Human Relations, Journal of Organizational Behavior, Journal of Managerial Issues, Management Decisions, Business Case Journal, and the International Journal for Human Resource Management. Dr. McIntyre's current research interests include curiosity, self concept-based motivation, emotional intelligence, and perfectionism.

\section{REFERENCES}

1. $\quad$ Are parents killing their kid's careers? Forbes, November 9, 2006.

2. Armour, S. (2007). Helicopter parents hover when kids job hunt. USA Today, April 23.

3. Arnett, J. (2007). Socialization in emerging Adulthood: From the family to the wider world, from socialization to self-socialization. In Handbook of Socialization, Eds. Joan Grusec \& Paul Hastings, p. 208230, New York: Guilford Press.

4. Cline, F.W., \& Fay, J. (1990), Parenting with Love and Logic: Teaching Children Responsibility. Colorado Springs, CO: Pinon Press.

5. Gardner, P. (2007). Parent involvement in the college recruiting process: To what extent? Retrieved from: http://ceri.msu.edu/publications/pdf/ceri2-07.pdf Michigan State University Collegiate Employment Research Institute.

6. Howe, N., \& Strauss, W. (2000). Millennials Rising: The Next Great Generation. New York: Vintage Books.

7. Junco, R., \& Mastraodicasa, J. (2007). Connecting to the net generation: What higher education professionals need to know about today's students. Washington, D.C.: NASPA.

8. Lipka, S. (2007). Helicopter parents help students, survey finds. Chronicle of Higher Education, November 9, 2007.

9. Lum, L. (2006). Handling helicopter parents. Diverse Issues in Higher Education, 23, 40-42.

10. Matthews, V. (2008). Debunking the myths about Generation Y. Personneltoday.com, September 14, Vol 21.

11. Neuharth, D. (1998). If you had controlling parents: How to make peace with your past and take your place in the world. New York: Harper Collins.

12. Raines, C. (2003). Connecting Generations: The Sourcebook for a New Workplace. Florence, KY: Cengage Learning.

13. Shellenbarger, S. (2006). Helicopter parents go to work: Moms and dads re now hovering at the office. The Wall Street Journal, March 16, pg. D1.

14. Somers, P., \& Settle, J. (2008). Helicopter Parents: An Exploratory Study. Working paper. 


\section{NOTES}

